\title{
Brief report Evaluation of genetic variability in introduced populations of red deer (Cervus elaphus) using DNA fingerprinting
}

\author{
T. PÉREZ 1 J. ALBORNOZ ${ }^{1}$, C. NORES ${ }^{2}$ and A. DOMÍNGUEZ \\ ${ }^{1}$ Departamento de Biología Funcional, Area de Genética. Universidad de Oviedo, 33071 Oviedo, Spain \\ ${ }^{2}$ Instituto de Ordenación del Territorio y Recursos Naturales, Universidad de Oviedo, 33071 Oviedo, Spain
}

(Received May 15, 1998. Accepted June 15, 1998)

Wild populations of large mammals are exposed to the effects of human activity that directly or indirectly disturb them and lead to population size reduction and occasionally to local extinctions. Consequently, the need for specific programmes to conserve them is progressively increasing (O'BRIEN 1998). Among the practices in conservation biology is the translocation of foreign individuals to increase genetic variability, or to reintroduce species in historically occupied ranges. The success of translocations is highly variable and dependent on species and founder size among other factors (GRIFFITH et al. 1989). Population genetics predicts that the maintenance of variability is important for population survival since its reduction could lead to inbreeding depression and low adaptation capability (FALCONER and MACKAY 1996). Hence, it is important to know the effects of translocations on genetic variability. Some studies have shown a reduction of genetic variability after translocation (SCRIBNER and STÜWE 1993; LEBERG et al. 1994; FITZSIMMONS et al. 1997), but experimental work on this subject is still scarce.

The red deer (Cervus elaphus) is widely distributed in Europe. In Spain its distribution has narrowed drastically in the first half of the 20th century. Native populations of the northern half of the Iberian Peninsula became extinct due to large-scale hunting, and were later reintroduced in virtually all their historical range (BRAZA et al. 1989).

The aim of this work is to study the success of reintroductions in maintaining genetic diversity. We apply DNA fingerprinting, revealed as a powerful technique in the study of the genetic structure of populations (ARMOUR and JEFFREYS 1992), to study Cantabrian populations of red deer which have quickly expanded after introduction, and compare them with their populations of origin regarding genetic variability.

\section{MATERIALS AND METHODS}

The three reintroduced populations studied (Caso, Somiedo and Sueve) are located in the region of
Asturias, in the northern side of the Cantabrian Mountains, in three areas that are isolated from each other by roads, railways and densely populated zones. Founder animals were from two reserves, Quintos de Mora (Toledo) and Lugar Nuevo (Jaén) in the main red deer native range of distribution (Fig. 1). Each of these reserves is at present enclosed with wire fences and maintain a large population size above 2000 individuals (AlvareZ 1988; ORTUÑO and De LA PeÑa 1979). Individuals from these two reserves were introduced in Asturias between the years 1950 and 1972 (NORES and VAZQUEZ 1987): 98 individuals (sex ratio unknown) were released in Caso in 1952-56, 126 individuals ( 33 males, 63 females and 30 unknown) were introduced in Somiedo in 1969-72 and 14 individuals (7 males and 7 females) were released in Sueve in 1970. Populations increased in number quickly after introduction, reaching at the time of this study approximate population sizes of 4000,1000 and 80 , respectively.

Muscle samples were taken from a total of 41 red deer shot during the hunting season of 1995-96. These came from the three repopulated areas in Asturias (12 from Caso, 13 from Somiedo and 4 from Sueve) and the two native areas (6 from Jaén and 6 from Toledo) from which reintroduced individuals came.

Probes 33.15 and 33.6 (JEFFREYs et al. 1985a; JEFFREYS et al. 1985b) were used to obtain fingerprints. All the samples were run in the same gel, dispersing samples from the same locality across separate lanes. Genomic DNA extraction, restriction with Hae III, Southern blotting, hybridization and analysis of fingerprints were performed as described (Pérez et al. 1996).

Heterozygosity was estimated following STEPHENS et al. (1992) from band frequency. Similarity coefficient $\left(S_{x y}\right)$ between each pair of individuals $(x$ and $y)$ was calculated as the number of common bands in their fingerprint profiles $\left(\mathrm{n}_{\mathrm{xy}}\right)$ divided by the average number of bands scored for both individuals: $S_{x y}=$ $2 \mathrm{n}_{\mathrm{xy}} /\left(\mathrm{n}_{\mathrm{x}}+\mathrm{n}_{\mathrm{y}}\right)$ (LYNCH 1990). Population subdivision was analyzed by studying the index of dissimilarity 

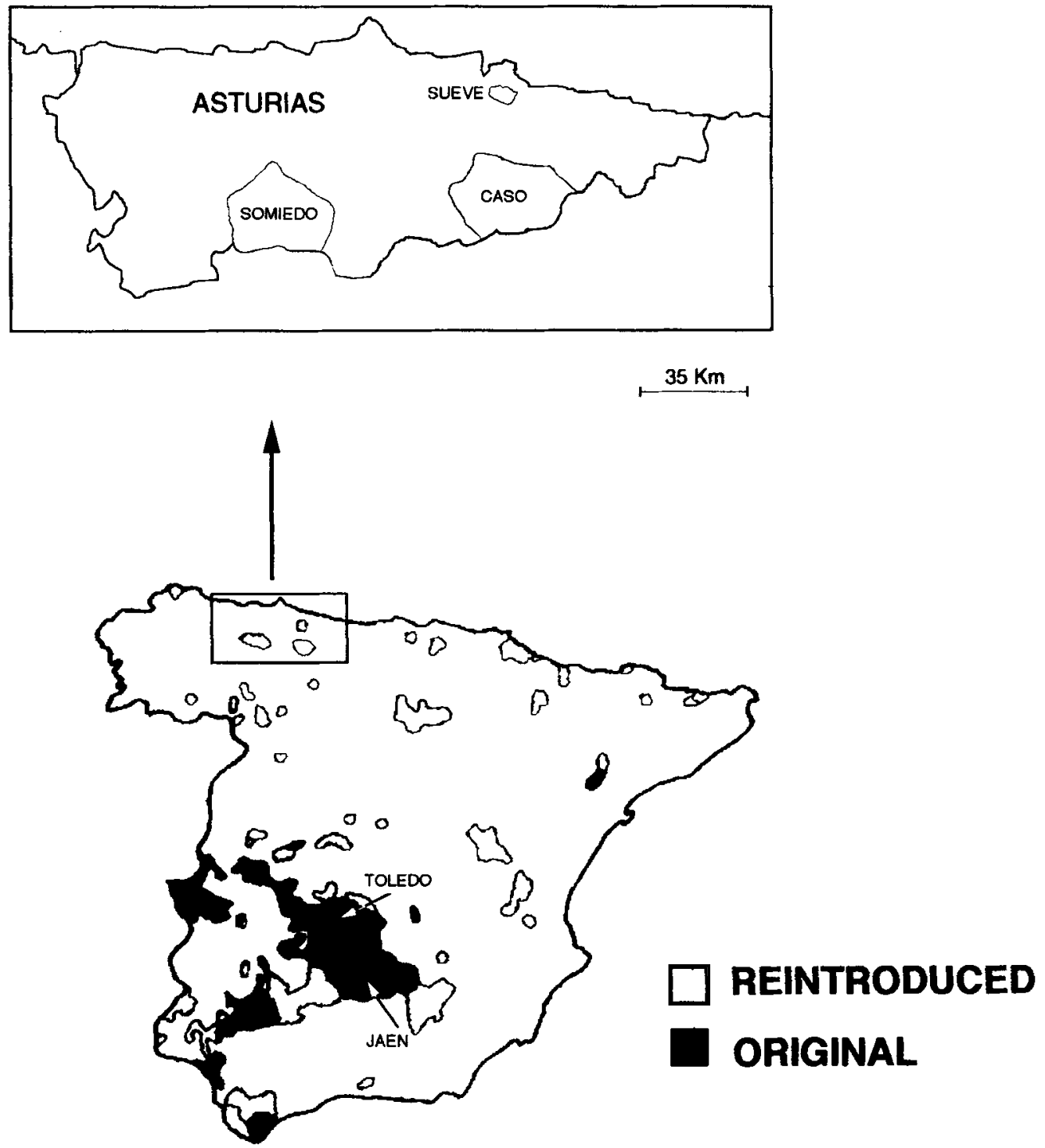

Fig. 1. Distribution of original and reintroduced red deer in Spain as depicted from (BRAZA et al. 1989).

$\overline{\mathrm{D}}_{\mathrm{ij}}=\left(\overline{\mathrm{S}}_{\mathrm{i}}+\overline{\mathrm{S}}_{\mathrm{j}}\right) / 2-\overline{\mathrm{S}}_{\mathrm{ij}}^{\prime}$, where $\overline{\mathrm{S}}_{\mathrm{i}}$ is the average similarity of individuals within population $i$ and $\bar{S}_{\mathrm{ij}}^{\prime}$ is the average similarity between random pairs of individuals across populations $\mathrm{i}$ and $\mathrm{j}$ (LYNCH 1990, 1991). The expected value for this index lies between 0 , when there is no subdivision between populations, and 1 when populations are fixed for different alleles. Sampling variances for mean similarity indices were estimated by the formulae of LYNCH $(1990,1991)$. All coefficients and errors were calculated using a computer program written for this purpose in BASIC (available on request). Following LYNCH (1990), indices were compared by a z-test. Significance was corrected following the sequential comparison method of Bonferroni (RICE 1989) to amend for non-independent multiple comparisons.
An almost unbiased estimate of $\mathrm{F}_{\mathrm{ST}}$, Wright's index of population subdivision, was estimated following LYNCH (1990): $F_{S T}^{\prime}=D_{b} /\left(D_{w}+D_{b}\right)$ where $D_{b}$ is the average value of $\bar{D}_{i j}$ over all $i, j$ and $D_{w}$ is the average value of $1-\bar{S}_{i}$ over all $i$.

\section{RESULTS}

All bands obtained with either probe were polymorphic and none was population specific. The two probes gave alike similarity and heterozygosity coefficients (Table 1). Band number ranged between 14 and 30 with a mean of 21.49 for probe 33.15 and between 7 and 16 with a mean of 10.32 for probe 33.6. The approximate number of loci studied (equal to $\mathrm{n}(4-\mathrm{S}) / 4(2-\mathrm{S})$, LYNCH 1990,1991$)$ was larger for probe 33.5. Consequently, the individual identifi- 
Table 1. Data from DNA fingerprints with probes 33.15 and 33.6. Total number of different bands scored, average band frequency \pm standard error (S.E.), mean number of bands $(n) \pm$ standard error (S.E.), heterozygosity, mean similarity (S), approximated number of loci and individualisation power (Pf)

\begin{tabular}{llllllll}
\hline Probe & $\mathrm{n}^{\circ}$ of bands & Frequency \pm S.E. & $\mathrm{n} \pm$ S.E. & Heterozygosity & $\mathrm{S}$ & $\mathrm{n}^{\circ}$ loci & Pf \\
\hline 33.15 & 96 & $0.21 \pm 0.01$ & $21.49 \pm 3.55$ & 0.85 & 0.25 & 11.61 & $2.69 \mathrm{E}-18$ \\
33.6 & 61 & $0.17 \pm 0.02$ & $10.32 \pm 2.39$ & 0.88 & 0.21 & 5.49 & $2.28 \mathrm{E}-09$ \\
\hline
\end{tabular}

cation power, of probe 33.15 was higher. The probability that any two profiles would be identical by chance (equal to $\left(1-2 \mathrm{~S}+2 \mathrm{~S}^{2}\right)^{\mathrm{n} / \mathrm{s}}$, (JONES et al. 1991)) is $2.69 \times 10^{-18}$ for probe 33.15 and $2.28 \times 10^{-9}$ for probe 33.6. Accordingly, the use of these probes would enable individual identification and paternity assignation.

Mean similarity indices for all pairwise comparisons within and across populations are presented in Table 2. Within population similarities $(\overline{\mathrm{S}} \mathrm{i})$ were equal except for the Sueve population that showed a greater similarity $(\mathrm{p}<0.001)$ than Somiedo, Toledo and Jaén, which denotes a lower level of heterozygosity.

The dissimilarity indices (Table 2) allow us to test whether there is less similarity between populations than expected on the basis of within population similarity. The dissimilarity index was significantly higher than zero for every comparison involving the Sueve population while it was equal to zero for every other comparison. Thus the Sueve population has been differentiated from the rest that are homogeneous. Mean $\mathrm{F}_{\mathrm{ST}}^{\prime}$ estimated for the pairs involving Sueve and each of the other populations was 0.07 . It is also possible to obtain an estimate of distance from $\mathrm{F}_{\mathrm{ST}}$, the coancestry distance $\mathrm{d}=-\ln \left(1-\mathrm{F}_{\mathrm{ST}}\right)$. This distance is appropriate for divergence due to drift only (WEIR 1996) and hence it is the parameter of choice for the present situation. Mean estimated distance between Sueve and the rest of the populations was 0.07 .

\section{DISCUSSION}

Theoretical considerations predict that the use of a limited number of founder individuals for introductions can lead to differentiation among populations and to a decrease of within population variability. These predictions have been shown to occur in reintroductions of mammals such as the alpine ibex (SCRIBNER and STÜWE 1993) or bighorn sheep (Fitzsimmons et al. 1997). Our study shows these effects for the population of Sueve founded from a small number of individuals. The small sample size available from this population could influence this result, particularly if by chance some of the individu- als sampled resulted to be close relatives. We can exclude this possibility by noting that the larger similarity index within this population is 0.35 . This value is far lower than expected for first degree relatives that, with a mean similarity for non-related individuals of 0.24 (excluding the population from Sueve), is $0.24+(1-0.24) / 2=0.62$. In addition, analysing a large number of loci per individual compensates for the low number of individuals in some samples. If we assume that DNA profiles obtained with probes 33.15 and 33.6 detect independent sets of variable DNA as in humans (JEFFREYS et al. 1986), by combining both probes we are studying a sample of 17 independent loci (Table 1).

The Sueve population was founded from 7 males and 7 females in 1970, three generations ago if we assume the generation time of 8.62 given by GAILLARD (1992), and expanded quickly to the approximate population size of 80 at present. Assuming an exponential growth in these first generations, the following population sizes can be estimated: $\mathrm{N}_{0}=14$, $\mathrm{N}_{1}=25, \mathrm{~N}_{2}=45$. Effective population size calculated as the harmonic mean of numbers in each generation is $\mathrm{N}=22$. The coancestry distance is related to $\mathrm{Ne}$, and $t$, the time in generations since populations diverged, $d_{t} \sim t / 2 \mathrm{Ne}$ (WEIR 1996). From this, a distance of 0.07 is expected, a value analogous to that observed. Populations of Somiedo and Caso, where the number of founders was around one hundred, have not been differentiated from the original populations as expected from considerations similar to the previous ones. It must be noted that those expectations are rather ideal ones. First, several factors reducing population size, and hence increasing expected distance, such as overlapping generations, differences in fertility or the polygynous nature of the species were not considered. Second, it is assumed that all released individuals survive and reproduce and that the population grows quickly and exponentially at a constant rate. The fact that observations fit expectations so well suggests that the later conditions must mostly be fulfilled.

Mean similarity index between non-related animals in the reduced population of Sueve was 0.30 , a value close to the similarity index of 0.31 obtained by PEMBERTON et al. (1992) for an isolated red deer 
Table 2. Similarity and dissimilarity indices with their standard errors. Average similarity of individuals within population $\left(\bar{S}_{i}\right)$, on the diagonal. Average similarity between pairs of individuals across populations $\left(\bar{S}_{i j}^{\prime}\right)$, above the diagonal. Index of dissimilarity $\left(\bar{D}_{i j}\right)$, below the diagonal. In parenthesis number of comparisons. ${ }^{* *} p<0.01$; $* * * p<0.001$

\begin{tabular}{|c|c|c|c|c|c|}
\hline & Caso & Somiedo & Sueve & Toledo & Jaén \\
\hline Caso & $\begin{array}{l}0.26 \pm 0.01 \\
(66)\end{array}$ & $\begin{array}{l}0.24 \pm 0.01 \\
(156)\end{array}$ & $\begin{array}{l}0.20 \pm 0.01 \\
(48)\end{array}$ & $\begin{array}{l}0.22 \pm 0.01 \\
(72)\end{array}$ & $\begin{array}{l}0.24 \pm 0.01 \\
(72)\end{array}$ \\
\hline Somiedo & $0.01 \pm 0.02$ & $\begin{array}{l}0.23 \pm 0.01 \\
(78)\end{array}$ & $\begin{array}{l}0.24 \pm 0.01 \\
(52)\end{array}$ & $\begin{array}{l}0.24 \pm 0.01 \\
(76)\end{array}$ & $\begin{array}{l}0.22 \pm 0.01 \\
(76)\end{array}$ \\
\hline Sueve & $0.07 \pm 0.02 * * *$ & $0.03 \pm 0.01 * *$ & $\begin{array}{l}0.30 \pm 0.01 \\
(6)\end{array}$ & $\begin{array}{l}0.22 \pm 0.01 \\
(10)\end{array}$ & $\begin{array}{l}0.22 \pm 0.02 \\
(10)\end{array}$ \\
\hline Toledo & $0.03 \pm 0.02$ & $0.00 \pm 0.01$ & $0.06 \pm 0.02 * *$ & $\begin{array}{l}0.24 \pm 0.03 \\
(15)\end{array}$ & $\begin{array}{l}0.23 \pm 0.01 \\
(36)\end{array}$ \\
\hline Jaén & $0.01 \pm 0.02$ & $0.01 \pm 0.01$ & $0.05 \pm 0.01^{* * *}$ & $0.00 \pm 0.01$ & $\begin{array}{l}0.24 \pm 0.01 \\
(15)\end{array}$ \\
\hline
\end{tabular}

population of rather reduced size from the Isle of Run (Scotland). Mean similarities obtained for the other four populations $(0.24)$ were in the order of values reported for human (JEFFREYS et al. 1985b) and natural populations (WETTON et al. 1987; BAKer et al. 1993; MörsCH and LeIBENGUTH 1994) and lower than the value of 0.44 recorded for the chamois (Rupicapra rupicapra) (PÉREZ et al. 1996) in the same area.

Our results provide evidence that reintroductions, even established with a relatively small number of individuals and dealing with a highly polygynous species, can reasonably maintain genetic variability. Comparable results were obtained from the analysis of protein polymorphism in enclosures of deer from Germany that originated from a few animals (HeRzOG et al. 1991). The low or negligible drift effects observed in this work, can be related to the rapid increase in population number after reintroduction that, in turn can be connected with a number of factors known to increase the success of translocations (GRIFFITH et al. 1989) such as translocation into the species historical range of distribution, habitat quality and the herbivore nature of the species.

\section{ACKNOWLEDGEMENTS}

This work was supported by PB-REC94-08 and PBREC96-16 from FICYT. T. Pérez was funded by the "Consejeria de Agricultura (Asturias)". We thank the "Guarderia de Caza" for providing the samples from Asturias, D. Gonzalez for the samples from Jaén and C. Rodriguez, J. M. Sebastian and R. Notario for the samples from Toledo.

\section{REFERENCES}

Alvarez G, (1988). Problemas asociados a la aplicación del transecto lineal para el censo de las problaciones de cérvidos en un biotopo mediterráneo (Quintos de Mora, Montes de Toledo). Ecología 2: 233-249.
Armour JA and Jeffreys AJ, (1992). Biology and applications of human minisatellite loci. Curr. Opin. Genet. Dev. 2: $850-856$.

Baker CS, Gilbert DA, Weinrich MT, Lambertsen R, Calambokidis J, Mcardle B, Chambers GK and O'Brien SJ, (1993). Population characteristics of DN fingerprints in humpback whales (Megaptera novaeangliae). J. Hered. 84: $281-290$.

Braza F, Varela I, San José C and Cases V, (1989). Distribution actuelle du chevreuil (Capreolus capreolus), du daim (Dama dama) et du cerf (Cervus elaphus) en Espagne. (Z. Säugetierkunde) 54: 393-396.

Falconer DS and MacKay TFC, (1996). Introduction to Quantitative Genetics. 4th edn. Longman.

Fitzsimmons NN, Buskirk SW and Smith $\mathrm{MH}_{\text {, (1997). }}$ Genetic changes in reintroduced rocky mountain bighorn sheep populations. J. Wildl. Manage. 31: 863-872.

Gaillard JM, (1992). Some demographic characteristics in Ungulate populations and their implication for management and conservation. Ongulés/Ungulates 91: 493-495.

Griffith B, Scott M, Carpenter JW and Reed C, (1989). Translocation as a Species Conservation Tool: Status and Strategy. Science 245: 477-480.

Herzog S, Mushövel $\mathrm{C}$, Hattemer $\mathrm{HH}$ and Herzog $\mathrm{A}$, (1991). Transferrin polymorphism and genetic differentiation in Cervus elaphus L. (European red deer) populations. Heredity 67: 231-239.

Jeffreys AJ, Wilson V and Thein SL, (1985a). Hypervariable 'minisatellite' regions in human DNA. Nature 314: $67-73$.

Jeffreys AJ, Wilson $\mathrm{V}$ and Thein SL, (1985b). Individual specific 'fingerprints' of human DNA. Nature 316: 7679.

Jeffreys AJ, Wilson V, Thein SL, Weatherall DJ and Ponder BAJ, (1986). DNA 'fingerprints' and segregation analysis of multiple markers in human pedigrees. Am. J. Hum. Genet. 39: 11-24.

Jones CS, Lessells CM and Krebs RJ, (1991). Helpers-atthe-nest in European Bee-eaters (Merops apieaster): A genetic analysis. In: DNA Fingerprinting Approaches and Applications, (eds) T Burke, G Dolf, AJ Jeffreys and R Wolff. Birkhauser Verlag, Basel, p. 169-192.

Leberg PL, Stangel PW, Hillestad HO, Marchinton RL and Smith MH, (1994). Genetic structure of reintroduced wild turkey and white-tailed deer populations. J. Wildl. Manage. 58: 698-711. 
Lynch M, (1990). The Similarity Index and DNA Fingerprinting. Mol. Biol. Evol. 7: 478-484.

Lynch M, (1991). Analysis of population genetics structure by DNA fingerprinting. In: DNA Fingerprinting Approaches and Applications, (eds) T Burke, G Dolf, AJ Jeffreys and R Wolff. Birkhäuser Verlag, Basel, p. 113126.

Mörsch G and Leibenguth F, (1994). DNA fingerprinting in roe deer using the digoxigenated probe $(G T G)^{5}$. Anim. Genet. 25: 25-30.

Nores C and Vazquez VM, (1987). La conservación de los vertebrados terrestres asturianos. Ministerio de Obras Públicas y Urbanismo, Centro de Publicaciones. Madrid.

Ortuño F and De La Peña J, (1979). Reservas y Cotos Nacionales de Caza. 4. Región Mediterránea. Incafo, Madrid.

O'Brien SJ, (1998). Genetic and phylogenetic analyses of endangered species. Annu. Rev. Genet. 28: 467-489.
Pérez T, Albornoz J, Garcia-Vazquez E and Domínguez A, (1996). Application of DNA Fingerprinting to Population Study of Chamois (Rupicapra rupicapra). Biochem. Genet. 34: 313-320.

Rice WR, (1989). Analyzing tables of statistical tests. Evolution 43: 223-225.

Scribner KT and Stüwe M, (1993). Genetic relationships among alpine ibex (Capra ibex) populations from a common ancestral source. Biol. Conserv. 69: 1-7.

Stephens JC, Gilbert DA, Ceci JD, Yuhki N and O'Brien SJ, (1992). Estimation of Heterozygosity for Single-Probe Multilocus DNA Fingerprints. Mol. Biol. Evol. 9: 729743.

Weir BS, (1996). Genetic Data Analysis II. Sinauer Associates Inc., Massachusetts.

Wetton JH, Carter R, Parkin DT and Walters D, (1987). Demographic study of a wild house sparrow population by DNA fingerprinting. Nature 327: 147-149. 